\title{
Demonic Beings in Ancient Egypt
}

\author{
Manal B. Hammad
}

\section{Introduction}

According to the ancient Egyptian religious concepts, the world was inhabited by six groups of superhuman beings; $n t r$

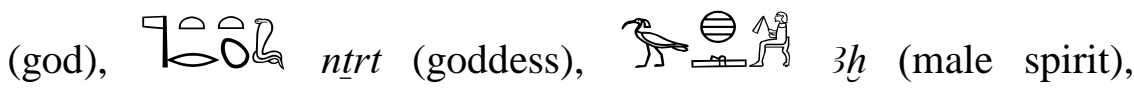

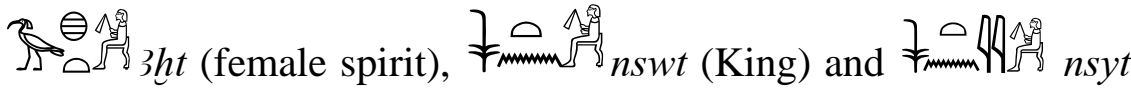
(queen). ${ }^{1}$ These categories were first followed by the humans in the royal domain who were in turn followed by officials, foreigners and then finally by commoners. ${ }^{2}$ These groups which were included in Onomastikon of Amenimopet, ${ }^{3}$ were considered to be part of the ordered cosmos. As for demons, they were excluded from these groups; not because they were nonexistent, but rather because they were beings of chaos. ${ }^{4}$ While, there is a collective term indicating the gods (ntrw) in ancient Egypt, which is the exact correspondent of the Greek 'theos. ${ }^{5}$ There is no collective term in the ancient Egyptian language that is equivalent to the English word Demon, ${ }^{6}$ which was originally driven from the

\footnotetext{
${ }^{1}$ GARDINER, A.H. (1947). Ancient Egyptian Onomastica, text Vol. I, London, 13. 2 SZPAKOWSKA, K. (2009). 'Demons in Ancient Egypt,' Religion Compass 3/5, 799.

${ }^{3}$ An ancient Egyptian papyrus the late twentieth Dynasty to the twenty second Dynasty which includes different groupings that include heavenly objects, towns, peoples and offices. See GARDINER, A.H. (1947). Ancient Egyptian Onomastica, text Vol. I, London.
}

${ }^{4}$ SZPAKOWSKA, K. (2009). 'Demons in Ancient Egypt,' Religion Compass $3 / 5,799$.

${ }^{5}$ LUCARELli, R. (2008). 'Between Men and Gods: Demons in Ancient Egypt,' Italian Academy Fellows' Seminar Working Papers, 1

6 MEEKS, D. (2001). 'Demons', in REDFORD, D.B. (ed.) The Oxford Encyclopedia of Ancient Egypt, Vol.1. New York, 375; WILKINSON, R.H. (2003). 'Demons', in The Complete Gods and Goddesses of Ancient Egypt, London, 81. 
ancient Greek term "daimon" that does not have an equivalent counterpart in the ancient Egyptian groups of beings. ${ }^{8}$ Therefore, the Egyptological literature assigned this term 'demon' to the study of these 'minor divinities, ${ }^{, 9}$ as a convention to fill the gap in the ancient Egyptian, which does not have a collective term for them. ${ }^{10}$

The ancient Egyptians believed that they were surrounded by supernatural powers that affected their fate not only in the earthly life but also in their afterlife. These fate demons ${ }^{11}$ were benevolent protectors that played the role of their guardian angels from anything that threatened their course of life. However these protector demons were not always able to safeguard them against the evil ones. ${ }^{12}$ Therefore, demons, in fact, played an important role in the ancient Egyptian culture and are evident in both the textual and material archaeological remains.

This article will shed light on the nature of these beings, their categories, roles and iconography based on magical spells and funerary texts from the Middle Kingdom down till the New Kingdom.

\section{Nature}

In ancient Egypt, demons ${ }^{13}$ were believed to have different origins; some were the creation of the gods for their personal

\footnotetext{
${ }^{7}$ BURNET, J.(1924) Plato's Euthyprho, Apology of Socrates and Crito, Oxford, 115; FULLER,H.(2013). From Daimon to Demon: The Evolution of the Demon from the Antiquity to Early Christianity, Masters thesis, Las Vegas, 17-18.

${ }^{8}$ LURCARELLI, R.(2010) 'Demons (Benevolent and Malevolent)', in DIELEMAN, J. and WENDRICH, W. (eds.) UCLA Encyclopedia of Egyptology, Los Angeles, 2; GARDINER, A.H. (1947). Ancient Egyptian Onomastica, text Vol. I, London, 13. ${ }^{9}$ WILKINSON, R.H. (2003). 'Demons', in The Complete Gods and Goddesses of Ancient Egypt, London, 81; MEEKS, D. (2001). 'Demons', in REDFORD, D.B. (ed.) The Oxford Encyclopedia of Ancient Egypt, Vol.1. New York, 375.

${ }^{10}$ SASS, D.(2014). Slaughterers, Knife-Bearers and Plague-Bringers, Masters thesis, Sydney, 20.

${ }^{11}$ Demons of fate are Shai, see LEITZ, C. (2002) Lexikon der ägyptischen Götter und Götterbezeichnungen VII, OLA 116, 4; His counterpart Renenet, see LEITZ, C. (2002) Lexikon der ägyptischen Götter und Götterbezeichnungen IV, OLA113, 686-689; Mesketet, see LEITZ, C. (2002) Lexikon der ägyptischen Götter und Götterbezeichnungen III,OLA 112,442-443.

12 MEEKS, D. (2001). 'Demons', in The Oxford Encyclopedia of Ancient Egypt I, Oxford, 375.

${ }^{13}$ VELDE, H. te, ' Damonen', in LÄ I, 980-984.
} 
purposes, while others were a result of human beings either dead or alive, being awakened for an individual permanently or occasionally. According to Meeks, these beings were assistants to major gods and goddesses, who limited themselves to inactivity with humans, who were instead contacted by demons. ${ }^{14}$ Thus they could be ranked as an intermediate between gods and mankind. ${ }^{15}$ The lack of designated cult places for the demons is an important distinction between them and deities ${ }^{16}$ at least till the New Kingdom. ${ }^{17}$ Demons possessed special powers that were not universal, but rather limited in nature and range. They tended to work in gangs of multiples of seven ${ }^{18}$ and they performed certain tasks upon command. ${ }^{19}$

Furthermore, they were defined as the "religious frontierstriders ${ }^{20}$ as they played a dual role, acting on the borders between order and chaos, embodying the ideas of $m 3^{2} t$ and $i s f t{ }^{21}$ as they

\footnotetext{
${ }^{14}$ MEEKS, D. (2001). 'Demons', in The Oxford Encyclopedia of Ancient Egypt I, Oxford, 375.

${ }^{15}$ VELDE, H. te, 'Damonen', in $L \ddot{A} I, 981$.

${ }^{16}$ ASSMANN, J. (2001). The Search for the God in Ancient Egypt, London, 7-8;
} LURCARELLI, R.(2013) 'Towards a Comparative Approach to Demonology in Antiquity: The Case of Ancient Egypt and Mesopotamia,' Archiv für Religionsgeschichte 14, 16-17.

${ }^{17}$ LURCARELLI, R.(2010). 'Demons (Benevolent and Malevolent)', in DIELEMAN, J. and WENDRICH, W. (eds.) UCLA Encyclopedia of Egyptology, Los Angeles, 2; SZPAKOWSKA, K. (2009). 'Demons in Ancient Egypt,' Religion Compass 3/5. It should be noted that from the late period onwards a union between the deities and the demons became clearly supported, an example of which is seen in the deity who was worshipped in the GrecoRoman period with his own temple cults yet with the qualities of a demon as one of his titles was the 'Master of Demons.' See KAPER, O.E. (2003). The Egyptian God Tutu: A study of the Sphinx-God and Master of Demons With a Corpus of Monuments. Orientalia Lovaniensia Analecta 119, Leuven. 60-63. ${ }^{18}$ MEEKS, D. (1971). 'Genies, anges, demons en Egypte', in GARELLI, P. (ed.) Genies Anges et Demons: Egypt - Babylone -Israel - Islam - Peuples altaiques - Birmanie - Asie du Sud-Est - Tibet - Chine, Sources Orientales 8, Paris, 44-45. ${ }^{19}$ WILKINSON, R.H. (2003). 'Demons', in The Complete Gods and Goddesses of Ancient Egypt, London, 81.

${ }^{20}$ AHN, G.(2006).'Demon / Demonology,' in STUCKRAD, V.K. (ed.), The Brill Dictionary of Religion, vol.1, Boston, 503.

${ }^{21}$ SASS, D.(2014). Slaughterers, Knife-Bearers and Plague-Bringers, Masters thesis, Sydney, 23. 
could be used as instruments of punishment against the evil or were able to save and help the good. ${ }^{22}$ They were associated with gods like Sekhmet, Hathor, Nekhbet, Osiris and $\mathrm{Ra}^{23}$

Demons do not dwell in the divine land of light or in temples, but they rather live in night, darkness or in natural places $^{24}$ such as desserts pools, rivers, streams, ponds, foreign places, ${ }^{25}$ mountains, ${ }^{26}$ as well as caves, pits, tombs, as all were considered doorways into the netherworld. ${ }^{27}$ They were not brightened by the sun, but were rather blind or sometimes they had an evil eye. They spoke no language, but incomprehensible howling and they were deaf. Moreover, they were smelly and they fed on waste matters. ${ }^{28}$ Gender was irrelevant to the role played by the demons, however most of the sources referred to male demons as for female ones rarely occurred. ${ }^{29}$

\section{Categories}

In ancient Egypt demons can act in pairs, in threes or in a gang, but nevertheless they can also manifest themselves as a single individual. ${ }^{30}$ Demons fall under two categories; the demons that inhabit the netherworld; these are stationary attached to a certain

${ }^{22}$ MEEKS, D. (1971). 'Genies, anges, demons en Egypte', in GARELLI, P. (ed.) Genies Anges et Demons: Egypt - Babylone -Israel - Islam - Peuples altaiques - Birmanie - Asie du Sud-Est - Tibet - Chine, Sources Orientales 8, Paris, 47-48.

${ }^{23}$ MEUER, G. (2002). Die Feinde des Konigs in den Pyramidentexten, Freiburg, 78.

${ }^{24}$ LEITZ, C. (2002). Lexikon der ägyptischen Götter und Götterbezeichnungen, II, OLA 111, 506.

${ }^{25}$ VELDE, H. te, ' Damonen', in $L \ddot{A}$ I, 981.

26 LURCARELli,R. (2010) 'Demons (Benevolent and Malevolent)', in DIELEMAN, J. and WENDRICH, W. (eds.) UCLA Encyclopedia of Egyptology, Los Angeles, 4.

${ }^{27}$ WILKINSON, R.H. (2003). 'Demons', in The Complete Gods and Goddesses of Ancient Egypt, London, 81.

${ }^{28}$ VELDE, H. te, 'Damonen', in $L \ddot{A}$ I, 981.

29 LURCARELLI, R.(2010) 'Demons (Benevolent and Malevolent)', in DIELEMAN, J. and WENDRICH, W. (eds.) UCLA Encyclopedia of Egyptology, Los Angeles, 6.

${ }^{30}$ LURCARELLI, R.(2010) 'Demons (Benevolent and Malevolent)', in DIELEMAN, J. and WENDRICH, W. (eds.) UCLA Encyclopedia of Egyptology, Los Angeles, 3. 
place that serves as their home. ${ }^{31}$ They are described and depicted in funerary literature, known as 'Guardians,' as they watch over the netherworld, ${ }^{32}$

As for the second category they are demons travelling between the earth and the beyond acting upon the world of the living by order of the gods and these are mentioned in magical spells and papyri as well as ritual texts. They are known as 'Wanderers, ${ }^{33}$ as they move from one place to another. They were connected to diseases, misfortune to humans, nightmares and demonic possessions. ${ }^{34}$

Despite the fact that these two categories of demons; of the both worlds are distinguished, yet they appear to complete each other in the religious belief in evil spirits. In other words, the demons that appear in the funerary texts may well be the same as those mentioned in amuletic and magical texts. ${ }^{35}$

\section{The guardian-demons}

The ancient Egyptian conception of the netherworld included many gates, portals, pylons and doors, ${ }^{36}$ which must be passed by the deceased to reach the place of the afterlife existence.

31 LURCARELLI, R.(2013) 'Towards a Comparative Approach to Demonology in Antiquity: The Case of Ancient Egypt and Mesopotamia,' Archiv für Religionsgeschichte 14, 17.

${ }^{32}$ LUCARELLI, R. (2008) 'Between Men and Gods: Demons in Ancient Egypt,' Italian Academy Fellows' Seminar Working Papers, 1

33 LURCARELLI, R.(2010) 'Demons (Benevolent and Malevolent)', in DIELEMAN, J. and WENDRICH, W. (eds.) UCLA Encyclopedia of Egyptology, Los Angeles, 2-3.

${ }^{34}$ LUCARELLI, R. (2008). 'Between Men and Gods: Demons in Ancient Egypt,' Italian Academy Fellows' Seminar Working Papers, 1

${ }^{35}$ LUCARELLI, R. (2006). 'Demons in the Book of the Dead', in BACKES, B., MUNRO, I. and STÖHR, S. (eds.), Totenbuch-Forschungen: Gesammelte Beiträge des 2. Internationalen Totenbuch-Symposiums, Bonn, 25. bis 29. September 2005,Leiden, 204

${ }^{36}$ LURCARELLI, R.(2010). ' The guardian- demons of the Book of the Dead', BMSAES 15, 86. 
Moreover, it was populated by these embodied creatures with supernatural powers, which are conventionally called s3wty.w 'guardian-demons. ${ }^{, 37}$ Their main function was restricted to the protection of the sacred passages, gates and doorways of the netherworld which they never leave, allowing no one in except those who belonged. ${ }^{38}$ Those 'door- watchers' or 'doorguardians, 'were depicted in the vignettes 145 and 146 of the Book of the Dead ${ }^{39}$ (fig.1) as triads of demons guarding 'rr.wt - gates of the house of Osiris: 1 iry-'3, 'the doorkeeper';

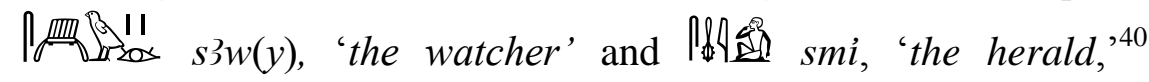
nevertheless, some variants of these spells depict each portal guarded by only one demon. ${ }^{41}$ Moreover, they acted as protectors of the King/justified deceased in his journey across the netherworld. ${ }^{42}$ Their protective function is related to the vigil of Osiris during the hours of the night, when his mummy needed protection before rebirth.

37 These entities were sometimes referred to as 'Genies' when they were depicted or mentioned in the temples, as their status changes from being guardians of the afterlife to being genies of the temple. They were introduced to the temple due to their skill in opening the way. See LUCARELLI, R. (2017) 'The Significance of the Book of the Dead Vignettes', in SCALF, F. (ed.), Book Of The Dead, Becoming God in Ancient Egypt, Chicago, 134; SZPAKOWSKA, K. (2009). 'Demons in Ancient Egypt,' Religion Compass 3/5, 802; LURCARELLI, R.(2010) 'Demons (Benevolent and Malevolent)', in DIELEMAN, J. and WENDRICH, W. (eds.) UCLA Encyclopedia of Egyptology, Los Angeles, 4.

${ }^{38}$ SZPAKOWSKA, K. (2009). 'Demons in Ancient Egypt,' Religion Compass $3 / 5,802$

${ }^{39}$ FAULKNER, R.O. (2010). The Ancient Egyptian Book of the Dead, Cairo, 134-135.

${ }^{40}$ LURCARELLI, R.(2010). 'The guardian- demons of the Book of the Dead', BMSAES 15, 87, 93;HART , G. (2005). The Routledge Dictionary of Egyptian Gods and Goddesses, 57-58.

${ }^{41}$ MUNRO, I. (1987). Untersuchungen zu den Totenbuch Papyri der 18. Dynastie: Kriterien ihrer Datierung. Studies in Egyptology, London.

${ }^{42}$ WILKINSON, R.H. (2003). 'Demons', in The Complete Gods and Goddesses of Ancient Egypt, London, 81. 


\section{B. HAMMAD, M}

They were not only described in the Book of the dead; vignettes 144 to 147 ( fig. 2 ), ${ }^{43}$ but also in other funerary books such as the Coffin texts ${ }^{44}$ and the New Kingdom Books of the Afterlife ${ }^{45}$ as well as on tomb walls. They were depicted in anthropomorphic forms with hybrid human-animal representations (fig.3a) that varied between reptiles, felines, canines, baboons, donkeys, goats, hippopotami, bulls, insects, scorpions and birds. Sometimes they are represented as monstrous representations combining two or more animals or animal and humans into one body. ${ }^{46}$ They were fully armed with traditional weapons such as knives, spears and daggers ${ }^{47}$ as well as ${ }^{2} h$ h signs, vegetal elements, ${ }^{48}$ torches and rearing cobras ${ }^{49}$ or upstanding lizards ${ }^{50}$ (fig.3b).

It seems that these demons were looked upon as beings of flesh and blood ${ }^{51}$ and that their physicality was the key to their power. This is confirmed by the fact that many names, titles and epithets of the demons refer to their physical attributes, which

${ }^{43}$ LURCARELLI, R.(2010). 'The guardian- demons of the Book of the Dead,' BMSAES 15, 86.

${ }^{44}$ Guardian - Demons were widely depicted on coffins to protect the mummies. BARGUET, P. (1967). Le Livre des morts des anciens egyptiens Litteratures anciennes du Proche Orient 1. Paris, 190,203.

${ }^{45}$ For More information on these books see HORNUNG, E.(1999) The Ancient Egyptian Books of the Afterlife, London.

${ }^{46}$ KAKOSY, L. (1982). 'Mischgestalt', in LÄ IV, 145-148.

${ }^{47}$ SZPAKOWSKA,K.(2009). 'Demons in Ancient Egypt,' Religion Compass 3/5, 802.

${ }^{48}$ LURCARELLI, R.(2010). 'The guardian- demons of the Book of the Dead', BMSAES 15, 86.

${ }^{49}$ MEEKS, D. (1971). 'Genies, anges, demons en Egypte', in GARELLI, P. (ed.) Genies Anges et Demons: Egypt - Babylone -Israel - Islam - Peuples altaiques - Birmanie - Asie du Sud-Est - Tibet - Chine, Sources Orientales 8, Paris, 17-84. ${ }^{50}$ LUCARELLI, R.(2017) 'Gods, Spirits, Demons of the Book of the Dead', in SCALF, F. (ed.), Book Of The Dead, Becoming God in Ancient Egypt, Chicago, 135.

51 HEERMA VAN VOSS, M. (1983), Vijf dekaden - Demonen da capo, Voordracht gehouden bij het tiende lustrum van het Vooraziatisch-Egyptisch Genootschap Ex Oriente Lux. Leiden, 7; LUCARELLI, R. (2006). 'Demons in the Book of the Dead', in BACKES, B., MUNRO, I. and STÖHR, S. (eds.), Totenbuch-Forschungen: Gesammelte Beiträge des 2. Internationalen Totenbuch-Symposiums, Bonn, 25. bis 29. September 2005, Leiden, 203. 
emphasize their aggressive dreadful nature. ${ }^{52}$ Among those are: 'the Swallower of Sinners,' 'the Bellower' and 'the Rapacious One. ${ }^{53}$ It is noteworthy to mention that, their names are rarely written with the determinative of divinity $\mathbb{N}$ (A40), ${ }^{54}$ but rather using a knife $\rightarrow$ (T31), a snake 6000 (I14) one of the above mentioned animals or even a dead man 55 (A15). Door-guardians can be malevolent guardians, hostile to humans, if they attempted to enter restricted zones without the appropriate knowledge. This explains why demons were well described and depicted pictographically in much detail so as the deceased would be able to visually recognize them and know their secret names ${ }^{56}$ in order to overcome their aggression $^{57}$ and pass through these different zones of the afterlife. ${ }^{58}$ Only then these guardians will serve as benevolent ones protecting Osiris/the justified deceased across the afterlife. Thus, they can be defined as lacking moral sense rather than evil ${ }^{59}$ as on one occasion, they can be a threat and on the other, they may be protective. ${ }^{60}$

${ }^{52}$ SZPAKOWSKA, K. (2009). 'Demons in Ancient Egypt,' Religion Compass 3/5,802; LUCARELLI, R. (2006).'Demons in the Book of the Dead', in BACKES, B., MUNRO, I. and STÖHR, S. (eds.), Totenbuch-Forschungen: Gesammelte Beiträge des 2. Internationalen Totenbuch-Symposiums, Bonn, 25. bis 29. September 2005, Leiden, 203.

${ }^{53}$ SZPAKOWSKA, K. (2009). 'Demons in Ancient Egypt,' Religion Compass $3 / 5,802$.

${ }^{54}$ Gardiner's sign-list, See GARDINER, A. H (1957). Egyptian Grammar. Being an Introduction to the Study of Hieroglyphs, Oxford, 528.

${ }^{55}$ VELDE, H. te, ' Damonen', in $L \ddot{A}$ I, 982.

${ }^{56}$ Humans gained superiority over these guardian- demons through the magical power associated with knowing their secret names. HART, G. (2005). The Routledge Dictionary of Egyptian Gods and Goddesses, 55; LURCARELLI, R.(2010). ' The guardian- demons of the Book of the Dead', BMSAES 15, 86.

${ }^{57}$ LURCARELLI, R. (2010) 'Demons (Benevolent and Malevolent),'in DIELEMAN, J. and WENDRICH, W. (eds.) UCLA Encyclopedia of Egyptology, Los Angeles, 5.

${ }^{58}$ MUNRO, I.( 2017) 'The Significance of the Book of the Dead Vignettes', in SCALF, F. (ed.), Book Of The Dead, Becoming God in Ancient Egypt, Chicago, 59; LURCARELLI, R.(2010). 'The guardian- demons of the Book of the Dead,' BMSAES 15, 89.

${ }^{59}$ VELDE, H. te, ‘ Damonen', in $L \ddot{A}$ I, 981.

${ }^{60}$ LUCARELLI, R. (2006). 'Demons in the Book of the Dead', in BACKES, B., MUNRO, I. and STÖHR, S. (eds.), Totenbuch-Forschungen: Gesammelte 
It is important to note that not only individual demons appear in the Book of the Dead, but also classes of demons with collective names, ${ }^{61}$ which operate both in the netherworld and on earth.

\section{The wanderer-demons}

These gangs of demons were rarely depicted, but rather mentioned through collective names ${ }^{62}$ in the amuletic and magical texts recorded on papyri and ostraka. ${ }^{63}$ Many of these gangs acted as troops at the service of major deities, particularly Ra, Osiris, Seth, Bastet and Sekhmet. ${ }^{64}$ It seems that these gangs usually comprised of seven members or even multiples of seven. They were generally

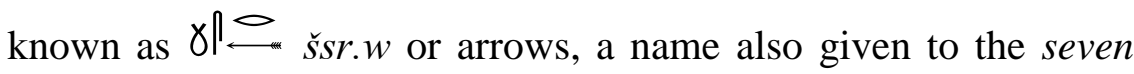
Decan stars, which are the closest to the sun. This explains the strong relationship between the demons and the astronomic cycles, that made their influence stronger on earth during specific dates, ${ }^{65}$ especially during the festival days, as confirmed by the calendars of Good and Bad ${ }^{66}$ and The Book of the Epagomenal Days of

Beiträge des 2. Internationalen Totenbuch-Symposiums, Bonn, 25. bis 29. September 2005,Leiden, 203.

${ }^{61}$ LUCARELLI, R. ( 2017). 'The Significance of the Book of the Dead Vignettes', in SCALF, F. (ed.), Book Of The Dead, Becoming God in Ancient Egypt, Chicago, 135; LUCARELLI, R. (2006). 'Demons in the Book of the Dead', in BACKES, B., MUNRO, I. and STÖHR, S. (eds.), TotenbuchForschungen: Gesammelte Beiträge des 2. Internationalen TotenbuchSymposiums, Bonn, 25. bis 29. September 2005, Leiden, 203.

62 LUCARELLI, R. ( 2017) 'The Significance of the Book of the Dead Vignettes', in SCALF, F. (ed.), Book Of The Dead, Becoming God in Ancient Egypt, Chicago, 135.

${ }^{63}$ Many of these spells were inscribed on clay ostraka, see LEITZ, C. (1999). Magical and Medical Papyri of the New Kingdom. Hieratic Papyri in the British Museum, Vol. 7, London.

${ }^{64}$ MEEKS, D. (2001). 'Demons', in The Oxford Encyclopedia of Ancient Egypt I, Oxford, 377.

${ }^{65}$ MEEKS, D. (2001). ' Demons', in The Oxford Encyclopedia of Ancient Egypt I, Oxford, 377.

${ }^{66}$ LURCARELLI, R.(2010) 'Demons (Benevolent and Malevolent)', in DIELEMAN, J. and WENDRICH, W. (eds.) UCLA Encyclopedia of Egyptology, Los Angeles, 3. 
Papyrus Leiden I 346, which confirms the importance of protecting the house against the turn of the year and the disease bringers. ${ }^{67}$

These šm3y.w 'wanderer demons' were responsible for illnesses, misfortunes and troubles to humans and their evil could be partially warded off only through magic. ${ }^{68}$ They even entered and haunted houses, which is evident from the magical spells ${ }^{69}$ made to defend different parts of the houses against those evil beings. ${ }^{70}$ They also outlined the frames of the false doors in their homes by the red paste, a protective color against the evil spirits and demons, so as not to enter the house through these open gates; the false doors. ${ }^{71}$ Furthermore, they attacked and entered the human body not only at night during sleep, but also by day causing what is known as demonic possessions. $^{72}$ Nightmares rsw.t $d w . t{ }^{73}$ were also included in Middle Kingdom execration texts among a long list of hostile doings these demons could do to harm an individual. Many spells and prescriptions survived especially from the New

${ }^{67}$ SASS, D.(2014). Slaughterers, Knife-Bearers and Plague-Bringers, Masters thesis, Sydney, 64

68 LURCARELLI, R.(2010) 'Demons (Benevolent and Malevolent)', in DIELEMAN, J. and WENDRICH, W. (eds.) UCLA Encyclopedia of Egyptology, Los Angeles, 3.

${ }^{69}$ BORGHOUTS, J. (1978) 'Ancient Egyptian Magical Texts,' Nisaba 9, Leiden, 10-11.

${ }^{70}$ LURCARELli, R.(2010) 'Demons (Benevolent and Malevolent)', in DIELEMAN, J. and WENDRICH, W. (eds.) UCLA Encyclopedia of Egyptology, Los Angeles, 4.

${ }^{71}$ False door within the premises of the houses of the living is most probably associated with the enactment of the ancestors' cult at home. HARRINGTON, N. (2013). Living with the Dead: Ancestor Worship and Mortuary Ritual in Ancient Egypt, Oxford, $67-71$.

${ }_{72}^{72}$ LURCARELLI, R.(2010) 'Demons (Benevolent and Malevolent)', in DIELEMAN, J. and WENDRICH, W. (eds.) UCLA Encyclopedia of Egyptology, Los Angeles, 4.

${ }^{73}$ KOUSOULIS, P. (2011). 'Ancient Egyptian Demonology, Studies on the Boundaries between the Demonic and the Divine in Egyptian Magic', Orientalia Lovaniensia Analecta 175, 64. 
Kingdom containing recipes of how to ward off those demons responsible for nightmares. ${ }^{74}$

Among these gangs also were than 0 h3ty.w ${ }^{75}$ 'the slaughterers. 'whose name was mentioned in the Pyramid Texts as early as the Old Kingdom, meaning that they were rather funerary, yet they were still mentioned in the medical-magical texts from the New Kingdom ${ }^{76}$ (fig.4) confirming their dual function in both the netherworld and the earthly life. The main role of the slaughterers, which was recorded as early as the Second Intermediate Period, ${ }^{77}$ was to bring diseases, illnesses and plagues. ${ }^{78}$ Sass, suggested that the development of this role grew from the close connection between their hieroglyphic name

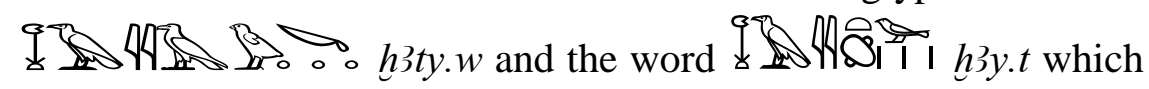
means disease. ${ }^{79}$ Moreover, they were emissaries of goddess Sekhmet, ${ }^{80}$ goddess of plague and fear, ${ }^{81}$ in her harmful aspect.

${ }^{74}$ KOUSOULIS, P. (2011). 'Ancient Egyptian Demonology, Studies on the Boundaries between the Demonic and the Divine in Egyptian Magic', Orientalia Lovaniensia Analecta 175, 67.

${ }^{75}$ LEITZ, C. (2002) Lexikon der ägyptischen Götter und Götterbezeichnungen $V$, OLA 114, 635-638.

${ }^{76}$ LUCARELLI, R. (2006). 'Demons in the Book of the Dead', in BACKES, B., MUNRO, I. and STÖHR, S. (eds.), Totenbuch-Forschungen: Gesammelte Beiträge des 2. Internationalen Totenbuch-Symposiums, Bonn, 25. bis 29. September 2005,Leiden, 204.

77 SASS, D.(2014). Slaughterers, Knife-Bearers and Plague-Bringers, Masters thesis, Sydney, 61.

${ }^{78}$ SCHIPPER, B.(2007). 'Angels or Demons? Divine Messengers in Ancient Egypt' in REITERER, F., NICKLAS, T. and SCHOPFLIN, K. (eds.), Angels: The Concept of Celestial Beings: Origins, Development and Reception, New York, 7.

${ }^{79}$ SASS, D.(2014). Slaughterers, Knife-Bearers and Plague-Bringers, Masters thesis, Sydney, 61.

${ }^{80}$ SCHIPPER, B.(2007). 'Angels or Demons? Divine Messengers in Ancient Egypt' in REITERER, F., NICKLAS, T. and SCHOPFLIN, K. (eds.), Angels: The Concept of Celestial Beings: Origins, Development and Reception, New York, 7.

${ }^{81}$ LUCARELLI, R. .( 2017) 'The Significance of the Book of the Dead Vignettes', in SCALF, F. (ed.), Book Of The Dead, Becoming God in Ancient Egypt, Chicago, 135. 
This is confirmed by the fact that they were stated in the Book of the Dead as haty.w shmt signifying their close relationship with the goddess, ${ }^{82}$ where the passages mentioned

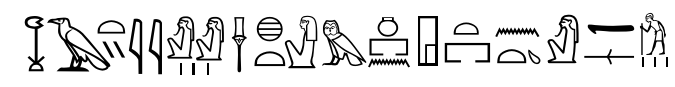

$i$ h3ty.w shmt m-hw.t i3w.w "the deceased praised the demons of Sekhmet in the House of the Elders"(fig.5)

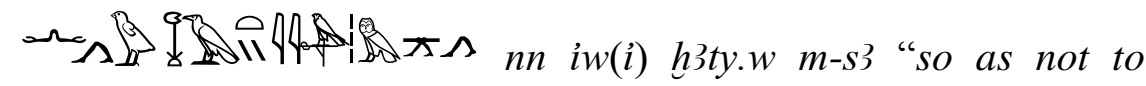
follow him." 83

Similarly most of the magical texts of the New Kingdom mention magical practices performed by the local magicians and priests in order to heal the living physically and/ or psychologically from the evil doings of the slaughterers. ${ }^{84}$ Spells were written on papyrus strips folded inside little containers and worn on necklaces to keep the demons away. ${ }^{85}$ Also, they were considered responsible for mental and internal diseases; and some were mentioned in the medical-magical texts of the Middle Kingdom onwards. Few of those demons were named as individuals in spells such as the demon $\breve{s} 3 k k^{86}$ who was blamed for the headache. ${ }^{87}$ He was depicted, in few Ramesside spells from Deir el Madina, ${ }^{88}$ as a

${ }^{82}$ LUCARELLI, R. (2006). 'Demons in the Book of the Dead', in BACKES, B., MUNRO, I. and STÖHR, S. (eds.), Totenbuch-Forschungen: Gesammelte Beiträge des 2. Internationalen Totenbuch-Symposiums, Bonn, 25. bis 29. September 2005,Leiden, 204.

${ }^{83}$ These passages are described in chapters 145, 149 of the Book of the Dead ( the Saite version), see LEPSIUS, R., (1842) Das Todtenbuch der Ägypter nach dem hieroglyphischen Papyrus in Turin, Leipzig, pl. 65.82, 86; LAPP, G. (1997) 'The Papyrus of Nu ( BM EA 10477)', Catalouge of the Books of the Dead in the British Museum, Vol. 1, London, pl. 83.44, 45.

${ }_{84}$ BORGHOUTS, J. (1978) 'Ancient Egyptian Magical Texts,' Nisaba 9, Leiden, 14-15.

${ }^{85}$ MEEKS, D. (2001). 'Demons', in The Oxford Encyclopedia of Ancient Egypt I, Oxford, 377.

${ }^{86}$ BORGHOUTS, J. (1978) 'Ancient Egyptian Magical Texts,' Nisaba 9, Leiden, 17.

${ }^{87}$ LEITZ, C. (2002) Lexikon der ägyptischen Götter und Götterbezeichnungen VI, OLA 115, 444-445.

${ }^{88}$ LURCARELLI, R.(2010) 'Demons (Benevolent and Malevolent)', in DIELEMAN, J. and WENDRICH, W. (eds.) UCLA Encyclopedia of Egyptology, Los Angeles, 3. 
naked child with a bad headache ${ }^{89}$ (fig. 6). Moreover, the demon $n s y$ and his female counterpart $n s y(t)^{90}$ who affected various parts of the body and might even cause death. ${ }^{91}$

Many of the spells against the demons were directed against the $m t(w)$ and the $3 h(w) .{ }^{92}$ The $m t(w)$ were the unjustified dead who were doomed ${ }^{93}$ and not admitted to the kingdom of the dead, so they became demons, ${ }^{94}$ ready to provoke the living in every way they could. This behavior is evident from a letters sent from a man to his deceased wife acting as an evil spirit against her living spouse which is causing him problems ${ }^{95}$ (fig.7). The importance of such a correspondence is based on the fact that it is showing the deceased souls who could turn into evil haunting spirits. The man in this letter is actually questioning the fact that he had not committed anything bad for his dead wife, stating all the good favors he had done to her during her life and also after her death; although she had caused him troubles. ${ }^{96}$

As for the $3 h(w)$,these were spirits belonging to the realm of the supernatural, however they were not independent entities like the gods or the demons, but they rather represented the

\footnotetext{
${ }^{89}$ WILKINSON, R.H. (2003). 'Demons', in The Complete Gods and Goddesses of Ancient Egypt, London, 81.

90 BORGHOUTS, J. (1978) 'Ancient Egyptian Magical Texts,' Nisaba 9, Leiden, 36-37.

${ }^{91}$ SZPAKOWSKA, K. (2009). 'Demons in Ancient Egypt,' Religion Compass $3 / 5,802$.

${ }^{92}$ These groups were referred to as both males and females. BORGHOUTS, J. (1978) 'Ancient Egyptian Magical Texts,' Nisaba 9, Leiden, 4.

${ }^{93}$ These probably transgressed against the gods, did not pass required tests for successful transformation or proper funerary rituals were not carried out.

94 VELDE, H. te, 'Damonen', in L̈̈ I, 982; SZPAKOWSKA, K. (2009). 'Demons in Ancient Egypt,' Religion Compass 3/5,800.

${ }^{95}$ For a full translation of this letter, see WENTE, E. (1990)'Letters from Ancient Egypt,' Society of Biblical Literature: Writings from the Ancient World 1, Atlanta, $216-217$.

96 TEETER,E. (1993) 'Popular Worship in Ancient Egypt', KMT 4, No. 2, 3536.
} 
modified status of the living after death. ${ }^{97}$ These glorified blessed spirits have been pious, committed no sins and thus were declared as justified. ${ }^{98}$ They were adored and venerated by being given an important position within the solar bark and had a special connection to god Re being his companions on his solar boat and hence known as the benevolent ghosts in the judgment of the deceased, which is evident by a number of spells in the Book of the Dead. ${ }^{99}$ They also acted as intermediates between the divinities and the mortals. ${ }^{100}$ However, as soon as they were neglected or not having a suitable place for to survive they might take a demonic form. ${ }^{101}$ These $3 h(w)$ - demons were mentioned in many spells of the daily and funerary magic. ${ }^{102}$

Another group of these gangs was messengers'. ${ }^{103}$ These were divine messengers sent to earth to act at the service of the Gods. Thus they could either play a positive or a negative role against those they face. ${ }^{104}$ They were associated with different deities; but frequently mentioned in funerary, magical and temple texts as the "messengers of Sekhmet,"105 and

97 LUCARELLI, R. ( 2017) 'The Significance of the Book of the Dead Vignettes', in SCALF, F. (ed.), Book Of The Dead, Becoming God in Ancient Egypt, Chicago, 136.

${ }^{98}$ FRIEDMAN, F.(1985). 'On the Meaning of Some Anthropoid Busts from Deir El-Medîna,' The Journal of Egyptian Archeology 71, London, 85.

${ }^{99}$ SZPAKOWSKA, K. (2009). 'Demons in Ancient Egypt,' Religion Compass $3 / 5,801$.

${ }^{100}$ DEMARÉE, R. J.(1983) 'The $3 h$ i $k r r n R^{\top}$-Stelae: On Ancestor Worship in Ancient Egypt', Egyptologische Uitgaven 3, Leiden, 283 - 284.

${ }^{101}$ VELDE, H. te, 'Damonen', in $L \ddot{A}$ I, 982.

102 BORGHOUTS, J. (1978) 'Ancient Egyptian Magical Texts,' Nisaba 9, Leiden, 19.

${ }^{103}$ SCHIPPER, B.(2007). 'Angels or Demons? Divine Messengers in Ancient Egypt' in REITERER, F., NICKLAS, T. and SCHOPFLIN, K. (eds.), Angels:

The Concept of Celestial Beings: Origins, Development and Reception, New York, 10.

${ }^{104}$ SCHIPPER, B.(2007). 'Angels or Demons? Divine Messengers in Ancient Egypt' in REITERER, F., NICKLAS, T. and SCHOPFLIN, K. (eds.), Angels: The Concept of Celestial Beings: Origins, Development and Reception, New York, 12.

${ }^{105}$ VELDE, H. te, 'Damonen', in $L \ddot{A}$ I, 983 
messengers of Seth, the god of chaos and evil. ${ }^{106}$ Moreover, they were associated with God Osiris, which is evident not only from the Coffin Texts that mentioned them as wpwty.w wsir, ${ }^{107}$ but also from ch. 125 of the Book of the Dead, where the deceased begs Osiris, lord of the Atef crown to save him from his messengers, who shoot forth harm and create punishments. ${ }^{108}$

One of the roles of these divine messengers was to punish the sinful in the Realm of the Dead, thus they were related to the last judgment (fig. 8). This is further confirmed by the text mentioned in ch.163 of the Book of the Dead (fig.9):

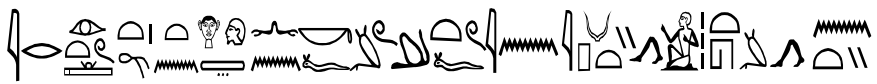

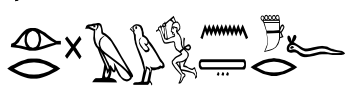

ir ir.tw md $3 t$ th hr tp t3 nn Kf3.tw. $f$ in ipwty.w th nty.(w) irr (w) sw3w $n$ t3 $\underline{d} r . f$ " 109 "If this book is used on earth, he shall not be seized by the messengers who attack those who commit wrong in the whole earth." 110 These messengers (punishers) were also sometimes depicted in scenes together with the same text used with the deceased's declaration of Innocence, ${ }^{111}$ which shows their close

106 LUCARELLI, R. ( 2017) 'The Significance of the Book of the Dead Vignettes', in SCALF, F. (ed.), Book Of The Dead, Becoming God in Ancient Egypt, Chicago, 136.

${ }^{107}$ LUCARELLI, R. (2006). 'Demons in the Book of the Dead', in BACKES, B., MUNRO, I. and STÖHR, S. (eds.), Totenbuch-Forschungen: Gesammelte Beiträge des 2. Internationalen Totenbuch-Symposiums, Bonn, 25. bis 29. September 2005, Leiden, 205.

${ }^{108}$ FAULKNER, R. (2010). The Ancient Egyptian Book of the Dead, Cairo, 33.

109 LEPSIUS, R., (1842) Das Todtenbuch der Ägypternach dem hieroglyphischen Papyrus in Turin, Leipzig, pl. 78.17, 18.

${ }^{110}$ LUCARELLI, R. (2006). 'Demons in the Book of the Dead', in BACKES, B., MUNRO, I. and STÖHR, S. (eds.), Totenbuch-Forschungen: Gesammelte Beiträge des 2. Internationalen Totenbuch-Symposiums, Bonn, 25. bis 29. September 2005, Leiden, 205.

${ }^{111}$ LUCARELLI, R. (2006). 'Demons in the Book of the Dead', in BACKES, B., MUNRO, I. and STÖHR, S. (eds.), Totenbuch-Forschungen: Gesammelte Beiträge des 2. Internationalen Totenbuch-Symposiums, Bonn, 25. bis 29. September 2005, Leiden, 205. 
connection with the forty two judges that witness the deceased's confession. ${ }^{112}$

Despite the fact that these messenger-demons usually acted as a gang, yet two of them were specifically mentioned independently in ch. 29 and 31 of the Book of the Dead (fig.10). In

ch. 29 the deceased addresses "Messenger of any god, get back, have you come to take away this heart of mine which belongs to the living? " Moreover, in ch. 31.for driving off a crocodile which comes to take away the deceased's magic from him in the realm of the dead, the deceased threatens to his to the Great God saying; 1 $w^{c}$ "Messenger is the name of one while Bedty is the name of the other." 113 Despite their frequent existence in funerary texts from the Old and Middle Kingdoms yet they were also widely mentioned in magical papyri ${ }^{114}$ and temple texts especially from the New Kingdom onwards. ${ }^{115}$

\section{Conclusions}

The ancient Egyptians believed in supernatural beings that closely affected their lives, their fate, their destiny and even their afterlife. Demons were in fact recognized by the ancient Egyptians despite the fact that they were never defined in the hierarchical list of their supernatural beings. These entities were believed to have consisted of subordinates and emissaries of the superior angry deities, damned unjustified dead, aggressive transformed spirits, and specialized gangs of demons. They were given names, titles and epithets that referred to their physical attributes and emphasized their aggressive dreadful nature. They lived in night, darkness or in natural places such as desserts, pools, rivers,

\footnotetext{
${ }^{112}$ VELDE, H. te, 'Damonen', in $L \ddot{A}$ I, 983.

${ }^{113}$ FAULKNER, R. (2010). The Ancient Egyptian Book of the Dead, Cairo, 54.

114 BORGHOUTS, J. (1978) 'Ancient Egyptian Magical Texts,' Nisaba 9, Leiden, 17.

${ }^{115}$ LUCARELLI, R. (2006). 'Demons in the Book of the Dead', in BACKES, B., MUNRO, I. and STÖHR, S. (eds.), Totenbuch-Forschungen: Gesammelte Beiträge des 2. Internationalen Totenbuch-Symposiums, Bonn, 25. bis 29. September 2005, Leiden, 206.
} 
streams, ponds, foreign places, mountains, as well as caves, pits, tombs, as all were considered doorways into the netherworld.

The ancient Egyptians categorized demons according to: their mobility, as some were stationary attached to a certain place that served as their home, while others moved between the earth and the beyond; also through their behavior, which was either benevolent or malevolent, hence were divided into sub-types. They mostly were either celestial guardian-demons who had a protective aggressive role to protect the gateways, regions and passages of the netherworld against those who did not belong. They were well described and depicted pictographically in much detail in the funerary texts, so as the deceased would be able to recognize them and know their secret names in order to overcome their aggression and pass through these different zones of the afterlife. They were depicted in anthropomorphic forms with hybrid human-animal representations and were fully armed with traditional weapons such as knives, spears and daggers.

The second type was the wanderer-demons. These gangs of demons were rarely depicted. They travelled between this world and beyond acting on behalf of their angry deities fulfilling their orders. They were malevolent causing illnesses, misfortunes, troubles and nightmares to humans. Moreover, they haunted their houses and caused possessions. As a result many magical spells were invented to create a safe protected space where demons were not allowed to enter. Nevertheless, the ancient Egyptians fear of demons continued and they interpreted any daily accidents or troubles to demonic acts. Accordingly and to appease them, from the Late Period onwards, some demons started to be worshiped and received a cult. 


\section{Demonic Beings in Ancient Egypt}
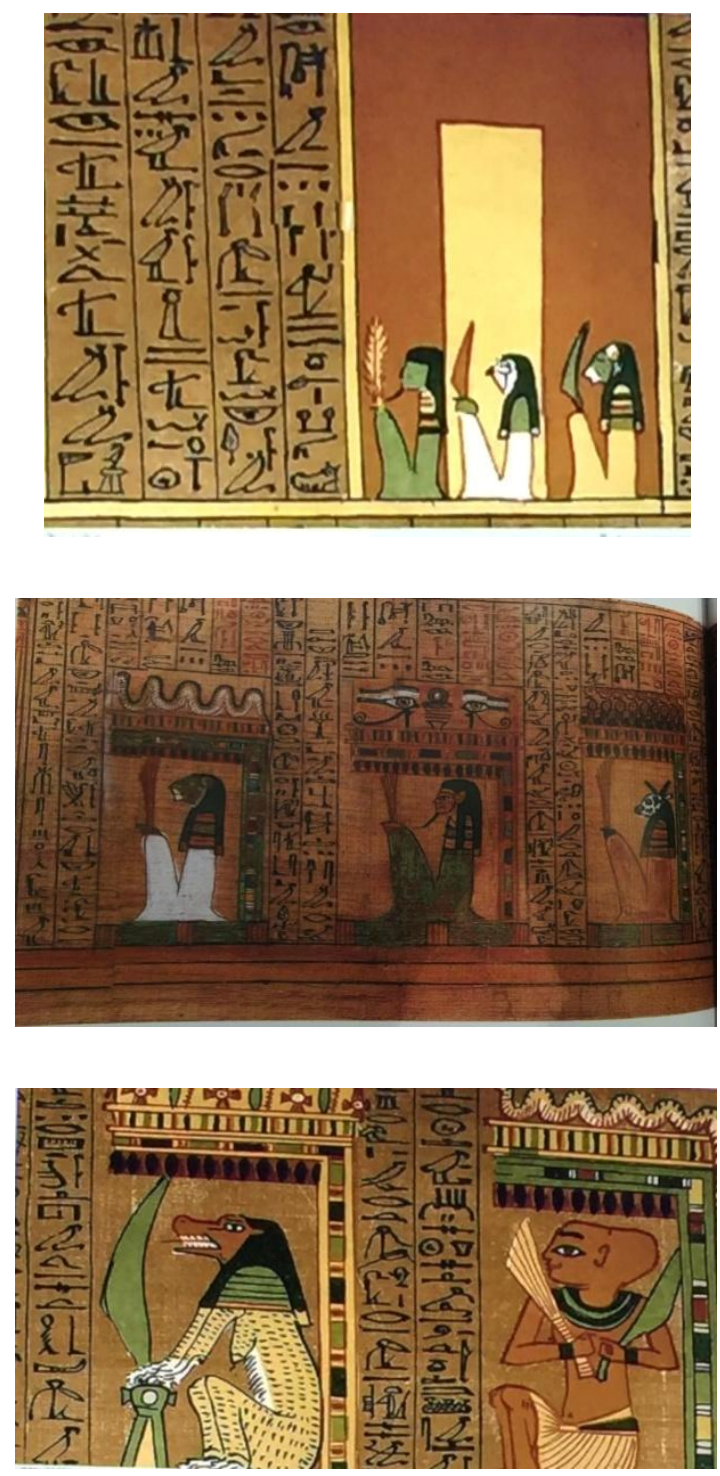

Fig. 1, Representing door- guardians from chapters 144 and 146 of the Book of the Dead. After, FAULKNER, R. (2010). The Ancient Egyptian Book of the Dead, Cairo, 134-135 and 138-139. 


\section{B. HAMMAD, M}
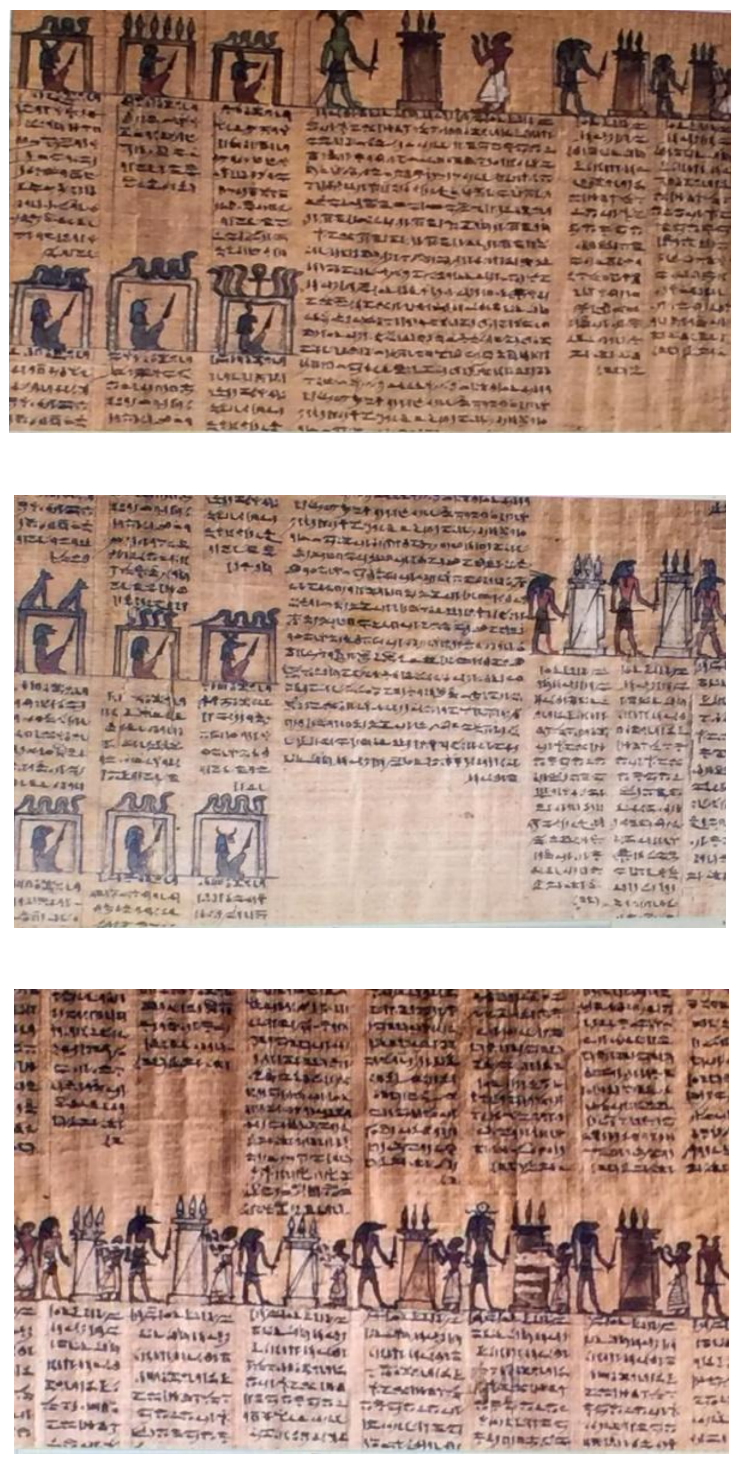

Fig. 2, Representing guardian demons in vignettes 146, 147 from the Book of the Dead. After, SCALF, F. (2017) Book Of The Dead, Becoming God in Ancient Egypt, Chicago, 236-237 


\section{Demonic Beings in Ancient Egypt}
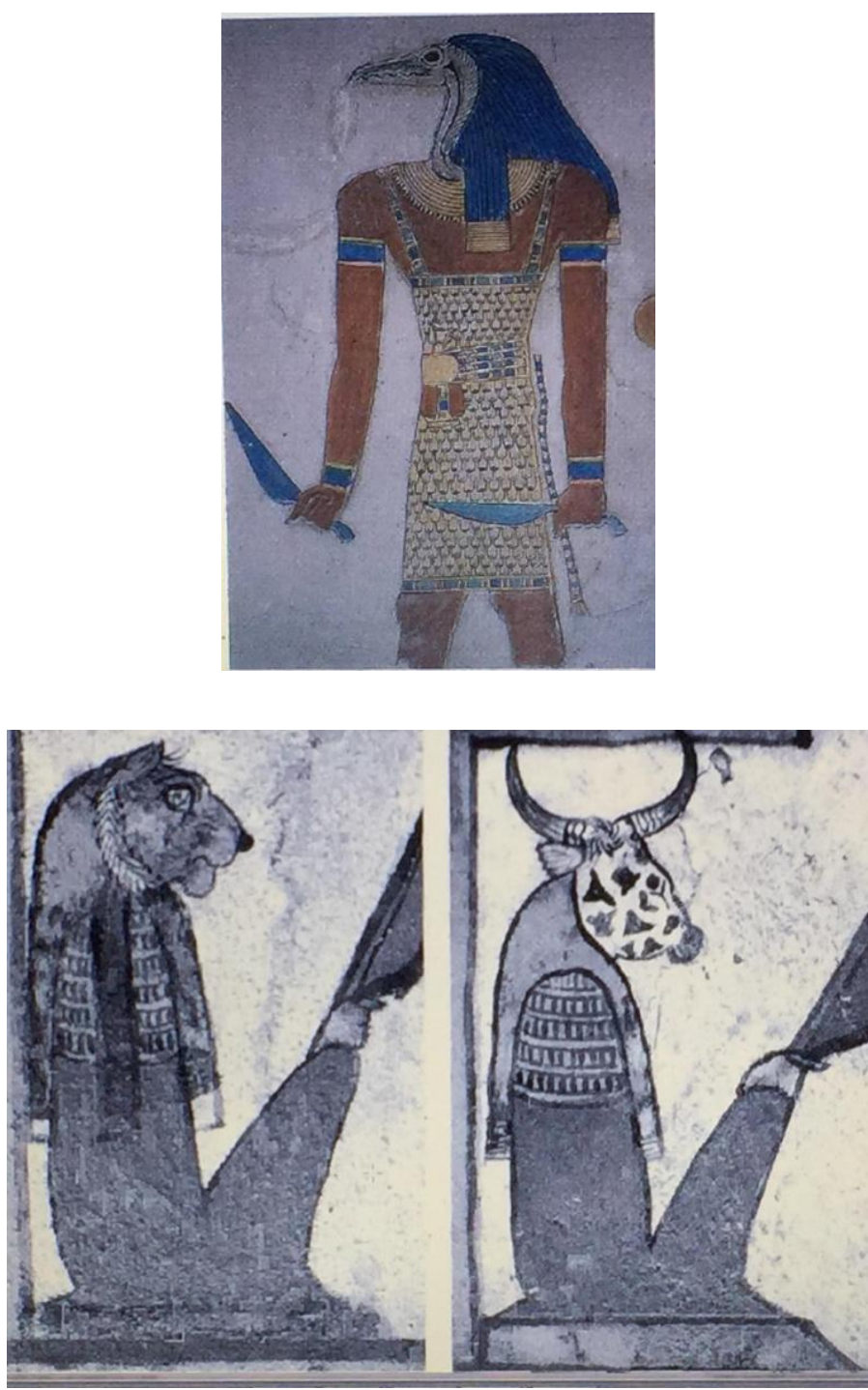

Fig. 3a, Representing guardian-demons in anthropomorphic forms with hybrid human-animal representations. After, WILKINSON, R.H. (2003). 'Demons', in The Complete Gods and Goddesses of Ancient Egypt, London, 81. 


\section{B. HAMMAD, M}

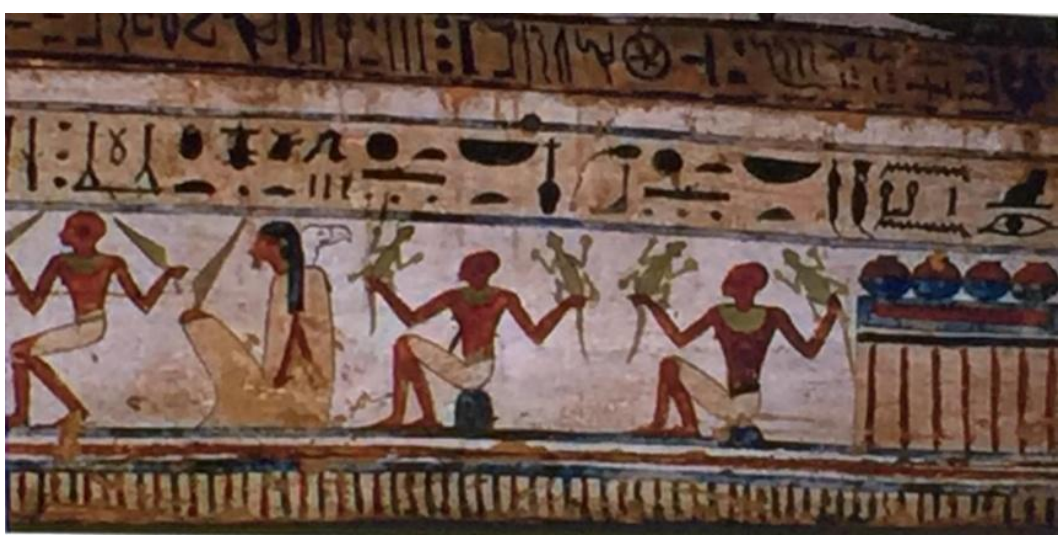

Fig. 3b, Representing guardian-demons holding traditional weapons such as knives and upstanding lizards depicted on the coffin of Horawesheb British museum EA 6666. After, SCALF, F.( 2017) Book Of The Dead, Becoming God in Ancient Egypt, Chicago, 134.

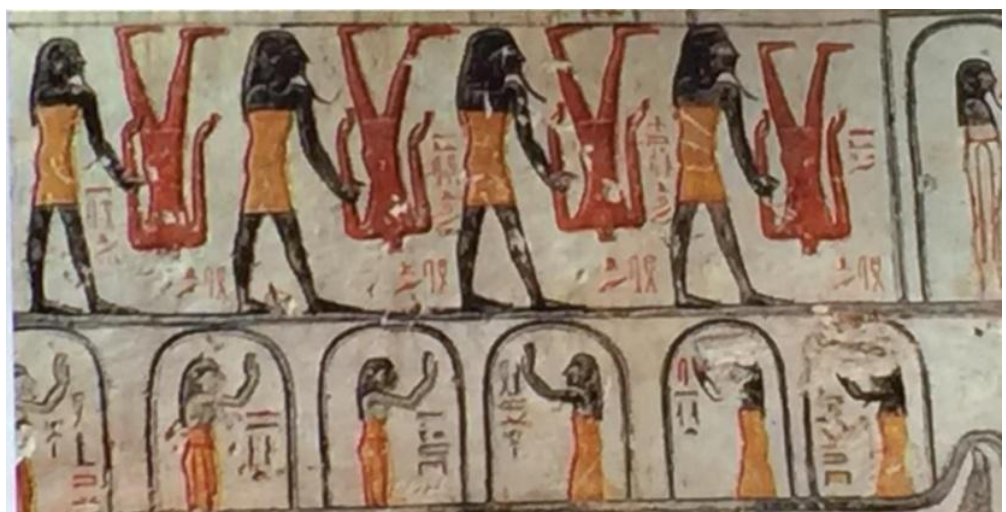

Fig. 4, Slaughtering-demons holding beheaded bodies of the damned from the tomb of Ramesses VI. After, SCALF, F.( 2017) Book Of The Dead, Becoming God in Ancient Egypt, Chicago, 58. 


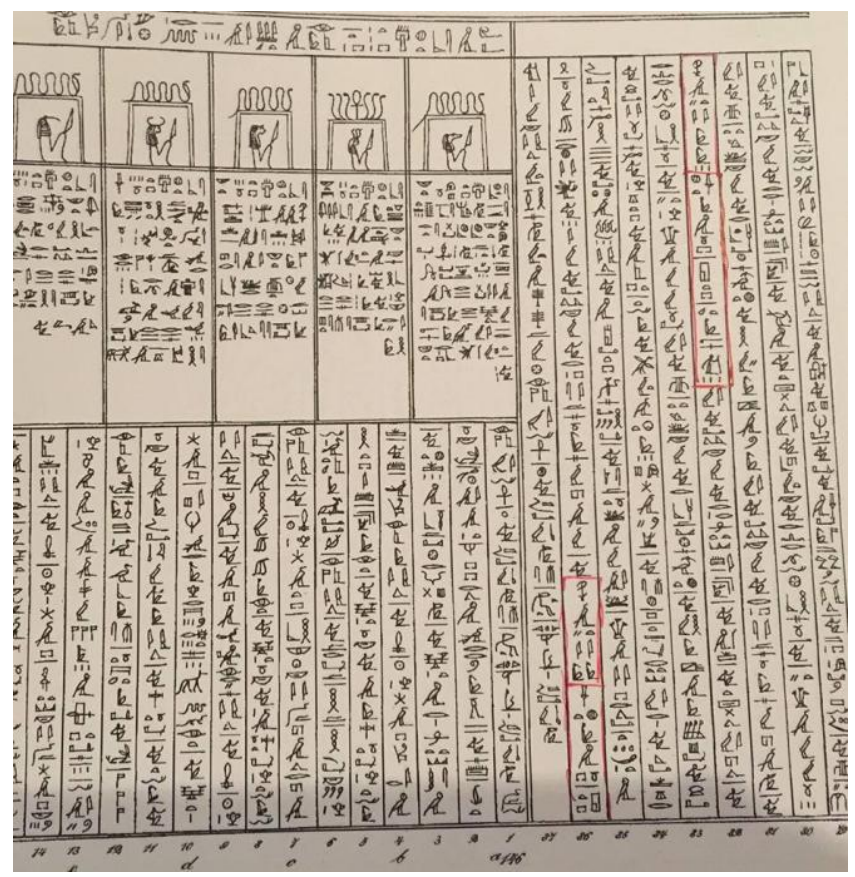

Fig. 5, Hieroglyphic texts confirming the close relationship between the slaughters and goddess Sekhmet. After, LEPSIUS, R., (1842) Das Todtenbuch der Ägypter nach dem hieroglyphischen Papyrus in Turin, Leipzig, pl. 65.82, 86.

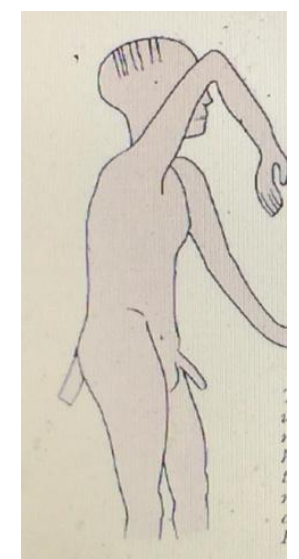

Fig. 6, Representation of demon $\check{s} 3 \mathrm{k} k$ who was blamed for the headache. After, WILKINSON, R.H. (2003). 'Demons', in The Complete Gods and Goddesses of Ancient Egypt, London, 81. 


\section{B. HAMMAD, M}

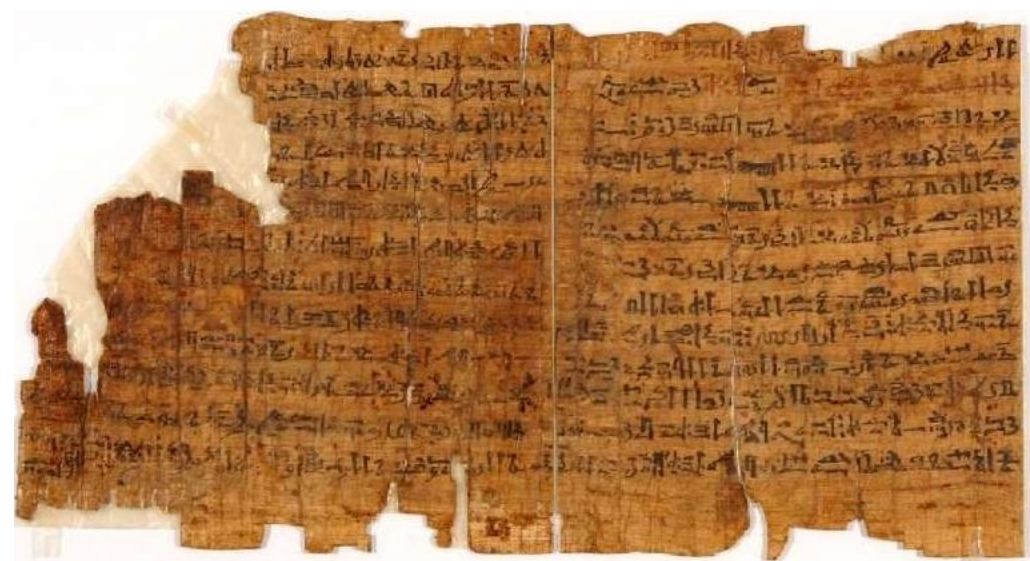

Fig. 7, A letter from a man to his deceased wife.After: The official website of the Egyptian museum in Leiden,

http://www.rmo.nl/collectie/zoeken?object=AMS+28+vel+3, accessed on April $26^{\text {th }}, 05: 23$ pm CLT

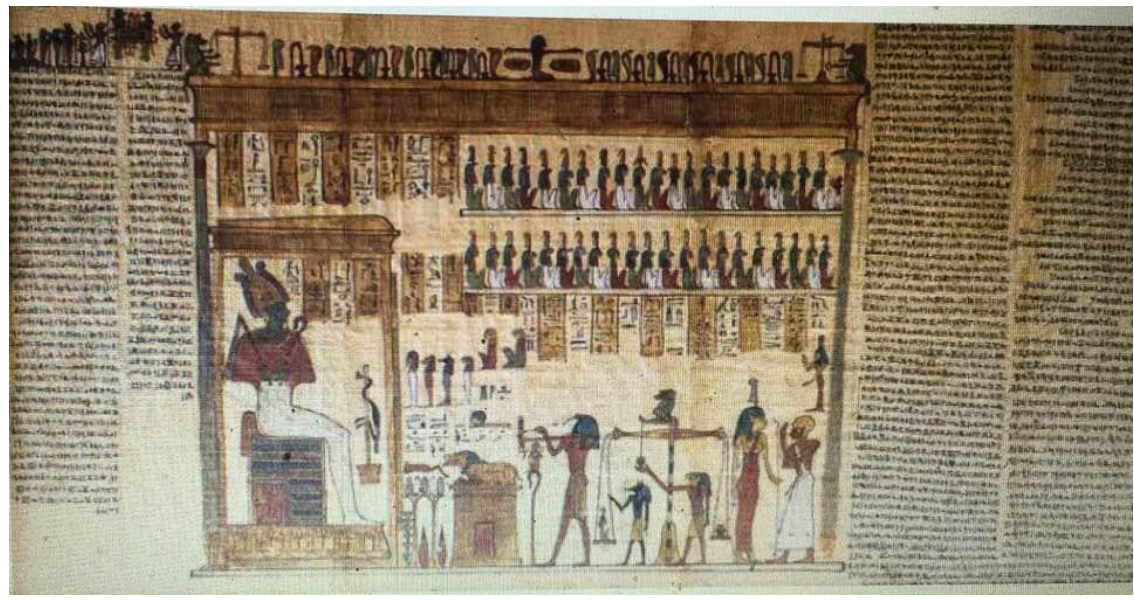

Fig. 8, Representing messengers who punish the sinful in the Realm of the Dead, vignette 125 of he Book of the Dead. After, SCALF, F. (2017) Book Of The Dead, Becoming God in Ancient Egypt, Chicago, 81. 


\section{Demonic Beings in Ancient Egypt}

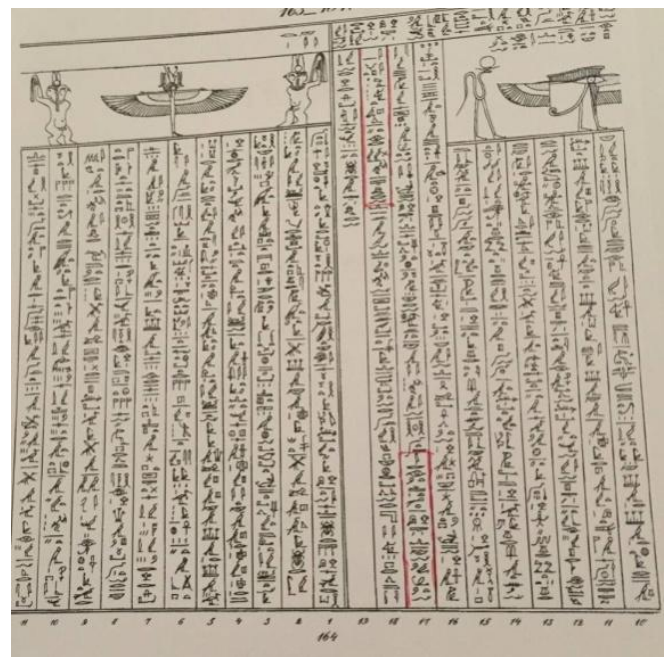

Fig. 9, Hieroglyphic texts confirming divine messengers will attack those who commit wrong in the whole earth. After, LEPSIUS, R., (1842)

Das Todtenbuch der Ägypter nach dem hieroglyphischen Papyrus in Turin,

Leipzig, pl. 78.17,18.

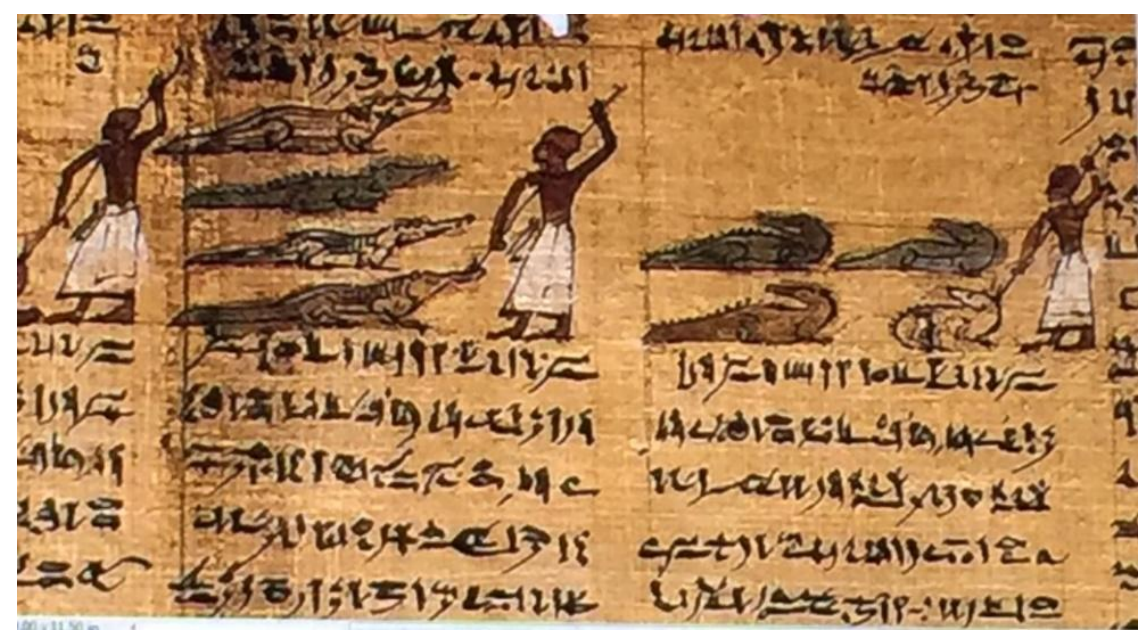

Fig. 10, representing ch. 31.of the Book of the Dead for driving off a crocodile which comes to take away the deceased's magic from him in the realm of the dead. After, SCALF, F.( 2017) Book Of The Dead, Becoming God in Ancient Egypt, Chicago, 114. 


\section{Bibliography}

AHN, G.,'Demon / Demonology,' in STUCKRAD, V.K. (ed.), The Brill Dictionary of Religion, vol.1, Boston (2006), 503-504.

ASSMANN, J., The Search for the God in Ancient Egypt, London (2001).

BARGUET, P., Le Livre des morts des anciens egyptiens Litteratures anciennes du Proche Orient 1. Paris (1967).

BORGHOUTS, J. 'Ancient Egyptian Magical Texts,' Nisaba 9, Leiden (1978).

BURNET, J., Plato's Euthyprho, Apology of Socrates and Crito, Oxford (1924), 115.

DEMARÉE, R. J 'The 3h ikn $n R^{\mathrm{e}}$-Stelae: On Ancestor Worship in Ancient Egypt', Egyptologische Uitgaven 3, Leiden (1983).

FAULKNER, R.O. The Ancient Egyptian Book of the Dead, Cairo (2010).

FRIEDMAN, F 'On the Meaning of Some Anthropoid Busts from Deir El-Medîna,' The Journal of Egyptian Archeology 71, London (1985), 8297.

FULLER, H. From Daimon to Demon: The Evolution of the Demon from the Antiquity to Early Christianity, Masters thesis, Las Vegas (2013).

GARDINER, A. H. Egyptian Grammar. Being an Introduction to the Study of Hieroglyphs, Oxford (1957).

(1947). , Ancient Egyptian Onomastica, text Vol. I, London

HARRINGTON, N., Living with the Dead: Ancestor Worship and Mortuary Ritual in Ancient Egypt, Oxford (2013). 67-71.

HART , G., The Routledge Dictionary of Egyptian Gods and Goddesses, (2005), 55-58.

HEERMA VAN VOSS, M., Vijf dekaden - Demonen da capo, Voordracht gehouden bij het tiende lustrum van het VooraziatischEgyptisch Genootschap Ex Oriente Lux. Leiden (1983).

HORNUNG, E., The Ancient Egyptian Books of the Afterlife, London (1999).

KAKOSY, L., 'Mischgestalt', in $L \ddot{A} I V$ (1982), 145-148.

KAPER, O.E., 'The Egyptian God Tutu: A study of the Sphinx-God and Master of Demons With a Corpus of Monuments, ' Orientalia Lovaniensia Analecta 119, Leuven (2003). 
KOUSOULIS, P.,'Ancient Egyptian Demonology, Studies on the Boundaries between the Demonic and the Divine in Egyptian Magic,' Orientalia Lovaniensia Analecta 175,(2011), 63-76.

LEITZ, C. Lexikon der ägyptischen Götter und Götterbezeichnungen (2002).

Magical and Medical Papyri of the New Kingdom. Hieratic Papyri in the British Museum, Vol. 7, London (1999).

LAPP, G. 'The Papyrus of Nu (BM EA 10477)', Catalogue of the Books of the Dead in the British Museum, Vol. 1, London (1997)

LEPSIUS, R., Das Todtenbuch der Ägypter nach dem hieroglyphischen Papyrus in Turin, Leipzig (1842).

LUCARELLI, R., 'The Significance of the Book of the Dead Vignettes', in SCALF, F. (ed.), Book Of The Dead, Becoming God in Ancient Egypt, Chicago (2017) 127-136.

'Towards a Comparative Approach to Demonology in Antiquity: The Case of Ancient Egypt and Mesopotamia,' Archiv für Religionsgeschichte 14, Online (2013) 11-25.

'Demons (Benevolent and Malevolent)', in DIELEMAN, J. and WENDRICH, W. (eds.) UCLA Encyclopedia of Egyptology, Los Angeles (2010), 1-10.

'The guardian- demons of the Book of the Dead', BMSAES 15 (2010), 85-102.

'Between Men and Gods: Demons in Ancient Egypt,'

Italian Academy Fellows' Seminar Working Papers, (2008).

'Demons in the Book of the Dead', in BACKES, B., MUNRO, I. and STÖHR, S. (eds.), Totenbuch-Forschungen: Gesammelte Beiträge des 2. Internationalen Totenbuch-Symposiums, Bonn, 25. bis 29. September 2005, Leiden (2006) 203-212.

MEEKS, D., 'Demons', in REDFORD, D.B. (ed.) The Oxford Encyclopedia of Ancient Egypt, Vol.1. Oxford (2001), 375-378

'Genies, anges, demons en Egypte', in GARELLI, P. (ed.)

Genies Anges et Demons: Egypt - Babylone -Israel - Islam - Peuples altaiques - Birmanie - Asie du Sud-Est - Tibet - Chine, Sources Orientales 8, Paris (1971), 17-84.

MEUER, G., Die Feinde des Konigs in den Pyramidentexten, Freiburg (2002).

MUNRO, I., 'The Significance of the Book of the Dead Vignettes', in SCALF, F. (ed.), Book Of The Dead, Becoming God in Ancient Egypt, Chicago (2017), 49-65. 


\section{B. HAMMAD, M}

., Untersuchungen zu den Totenbuch Papyri der 18. Dynastie:

Kriterien ihrer Datierung. Studies in Egyptology, London (1987).

SASS, D., Slaughterers, Knife- Bearers and Plague-Bringers, Masters thesis, Sydney (2014).

SCHIPPER, B. 'Angels or Demons? Divine Messengers in Ancient Egypt' in REITERER, F., NICKLAS, T. and SCHOPFLIN, K. (eds.), Angels: The Concept of Celestial Beings: Origins, Development and Reception, New York (2007), 1-19.

SZPAKOWSKA, K. 'Demons in Ancient Egypt,' Religion Compass 3/5 (2009), 799-805.

TEETER, E. 'Popular Worship in Ancient Egypt', KMT 4, No. 2, (1993). 28-37.

VELDE, H. te, 'Damonen', in LÄ I, 980-984.

WENTE, E., 'Letters from Ancient Egypt,' Society of Biblical Literature:

Writings from the Ancient World 1, Atlanta (1990).

WILKINSON, R.H. 'Demons', in The Complete Gods and Goddesses of Ancient Egypt, London (2003), 81-82.

AHN, G.,'Demon / Demonology,' in STUCKRAD, V.K. (ed.), The Brill Dictionary of Religion, vol.1, Boston (2006), 503-504. 